\title{
Models of management of the territorial community nature resources' rational use
}

\author{
Svitlana Ivanova ${ }^{1}$, Lyudmila Gainutdinova ${ }^{2}$, Sergiy Kvitka ${ }^{3, *}$, Mykhailo Shvydenko ${ }^{4}$, and \\ Olena Kulishova ${ }^{5}$ \\ ${ }^{1}$ Oles Honchar Dnipropetrovsk National University, 72 Haharina Ave, 49000 Dnipro, Ukraine \\ ${ }^{2}$ Herzen State Pedagogical University of Russia, 6 Kazanskaya st. 191186 St. Petersburg, Russia \\ ${ }^{3}$ Dnipropetrovsk Regional Institute of Public Administration National Academy of Public \\ Administration under the President of Ukraine, 29 Gogolia str., 49044 Dnipro, Ukraine \\ ${ }^{4}$ National University of Life and Environmental Sciences of Ukraine, 15 Heroyiv Oborony St., 03041 \\ Kyiv, Ukraine \\ ${ }^{5}$ Pryazovskyi State Technical University, 7 Universytetska st., 87555 Mariupol, Ukraine
}

\begin{abstract}
The aim of the article is to present the results of the applied research, carried out to develop a model of land and water resources management for a united territorial community. The material was prepared on the basis of the results, which had been obtained during the implementation of the project, aimed to developing a vision for the strategy of the territory development. Within the development of the vision, the strategy for the development of the territorial community has been collected in a certain way, and then, on the basis of this information, a so-called mental experiment has been carried out based on various methods of information analysis. In particular, it gave the opportunity to develop models for the use of community's land and water resources. Local governments should rely on carefully prepared information about available resources for more effective management of territories. One of the ways to get such information is the mental experiment method used with the aim of modeling potential ways of municipal territories' land and water resources rational use.
\end{abstract}

\section{Introduction}

During the process of decentralization in many countries, territorial entities are consolidated through their unification, which is made to increase common resources. It enables communities to become more independent, that is, allows them to make the transition from the category of subsidized to the self-sufficient ones. Most of these municipalities are located in rural areas, where their main resources in the climatic conditions of the European continent are water and land. Of course, minerals could also be an important resource, but the government always and everywhere leaves control over the use of mineral resources for itself. That's why, the prospects of territorial communities are connected with the effective use of nature resources: land and water resources.

\footnotetext{
* Corresponding author: skvitka14790@gmail.com
} 


\section{Methods}

The main method for collecting updated information is the Foresight technology [1], which is used in different countries of Europe and Asia to design the development of regions and territories. In this case, the Foresight technology has been used to conduct a study of territories that were united into a administrative unit Peshchanka (Dnipropetrovsk region, Ukraine).

The methodology for analyzing and synthesizing new management information when conducting mental experiments was based on the "info science" approach [2]. This made it possible to prepare a vision of community development that was understandable to the residents of the area in a fairly short time. Since, among other things, it took into account their points of view and wishes. Such a blitz presentation of information on a complex issue can be useful in various projects and activities.

To develop a truly strategic vision, it is necessary to be able to work with information, which means: it is necessary to be able to collect it in a certain way, to understand what is behind this information and to be able to give it in a convenient and understandable form for public authorities and for the population. Moreover, competent work with information can be considered as a key competence of heads of local self-government bodies [3].

\section{Results and discussion}

The development of a vision for the strategic development of the territorial community Peshchanka (Dnipropetrovsk region, Ukraine) [4] was carried out by collecting information and by organizing expert polls within the framework of Foresight technology.

The area of the community is 395.8 sq. $\mathrm{km}$. and it includes 4 previously isolated administrative units - the villages of Peshchanka, Orlovshchina, Znamenovka and the settlement of Meliorativnoe. The population is about 22,000 people. For comparison, the regional center Dnipro city, located in $40 \mathrm{~km}$, with the same territory has a population of about 1 million Water resources are the rivers Samara, Peshchanka, Kilchen and others, as well as there are more than 40 lakes (including one salt lake) and a source of mineral water in the village Znamenovka [4].

Preliminary desk researches have been carried out, which made it possible to formulate actual questions for each locality, and several general questions have been formulated for all localities. In addition, the practice of working with metaphors has been suggested, which showed that the population understands the uniqueness of the territory and its wealth, but does not know and have no skills how to use it.

Also, within the framework of the Foresight technology, expert interviews have been conducted with the representatives of local self-government bodies - including 37 members of local councils and municipal employees. The collective sessions were attended by 89 people. As a result of these sessions and interviews, sufficient material was collected and analyzed using the "affinity diagram" approach. The results of this analysis made it possible to formulate the priority tasks of the community's development, and also made it possible to formulate the main goals of the territory's development and to develop road maps for the use of land and water resources.

It should be noted that the design of a strategic vision for the development of the territory lies firstly at restructuring of management methods. First, it is necessary to see potential ways and then involve residents into the implementation process. The engagement process is through dialogue and discussion, as well as through finding solutions in a winwin approach. The scheme of forward movement from strategic vision to real projects is as follows [5]. 


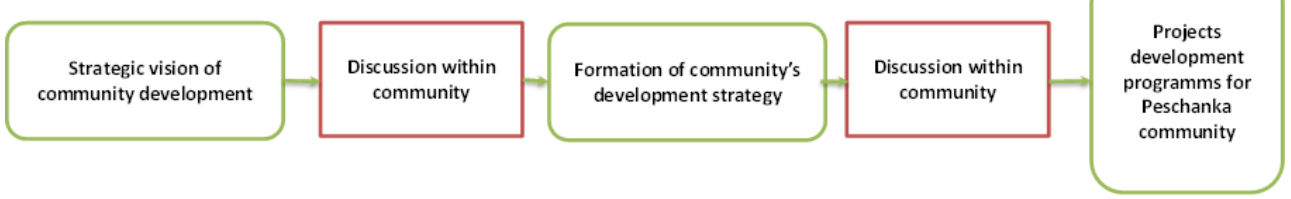

Fig. 1. The scheme of movement from a strategic vision to real projects.

At the same time, it should be kept in mind that, according to J. Gharajedagi [6], the systemic principles of openness, purposefulness, multidimensionality and emergence allow an object to develop as a dynamic whole. Particular difficulties arose from the strategies of using precisely the land and water resources in Peshchanka, the owners of which became the inhabitants of the community. It is worth clarifying that when the resources of all settlements were combined, the community received a unique set of potential opportunities, taking into account the actual resource wealth of the territory.

The use of "information science" approaches (for example, such as combination and modeling) allowed the development of clear mental maps for the systematic use of water and land resources [7]. As part of the analysis of the territory's water potential, basic opportunities for the development of the community have been identified. Given the presence of a large number of rivers, lakes and their condition, it has been suggested to develop various types of activities associated with mechanical and biological treatment of water bodies, as well as the development of fisheries and health resort infrastructure on their basis. In addition, the types of activities related to the purification of bodies of water have the potential for the further development (including the export of technologies, equipment and materials) both in the Dnipropetrovsk region and in other regions of the country and abroad. Based on the studies, the following model of water resources' use has been suggested (Fig. 2).

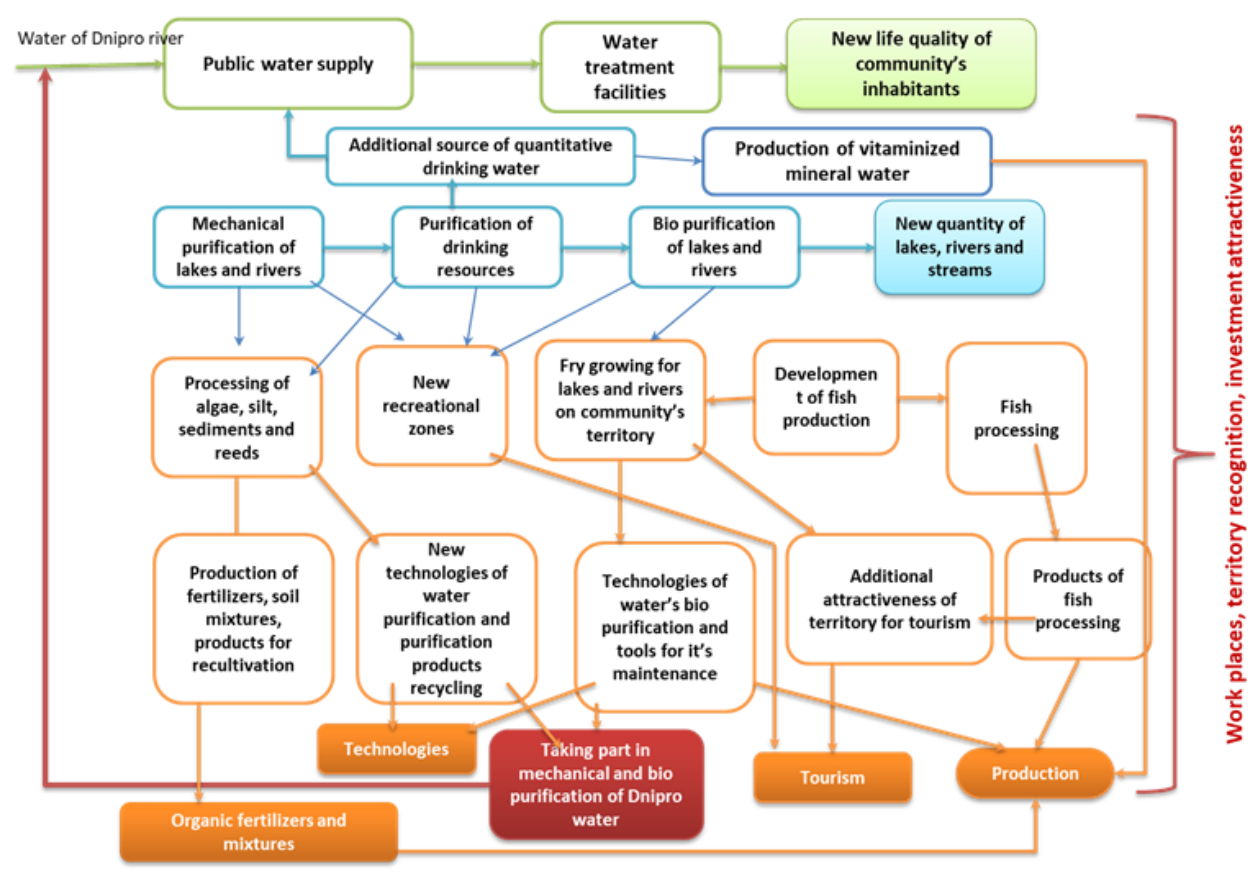

Fig. 2. The water potential of the community and its rational use. 
The analysis of the systemic interconnections of community territory's water resources made it possible to form pools of projects for the implementation: organization of works on cleaning territory's water bodies; development of technologies for mechanical and biological treatment of water bodies; processing of organic waste from water bodies cleaning into fertilizers and recultivation materials; organization of industrial enterprises (fish products, fry for bio-cleaning of water bodies, mineral water, fertilizers, soil mixtures, materials for recultivation, etc.); tourism (health, medical, green, water, fishing, etc.)

Thus, the rational use of the territory's water resources can give a powerful impetus to the development of the community, as well as to form its export potential (technologies and materials for biological treatment of water bodies) [8]. Also, the implementation of projects related to the purification of water bodies is an additional opportunity for projects of medical, recreational and tourist spheres. It should be kept in mind that this approach allows the locals to create a springboard for sustainable development of the territory, and also allows them to create new working places and innovative businesses [9-10]. At the same time, the residents' assessment of their quality of life and well-being changes [11], which means that there is a potential opportunity for the community to flourish [12-14].

Land as a resource of the territory makes it possible to develop crop and livestock raising, and forestry also. The territory is characterized by traditional plant growing crops: cereals, vegetables and fruit crops, berries. There are large and small greenhouse complexes (for growing flowers and vegetables). Livestock breeding traditionally had several directions in the region: meat and dairy production, poultry, horse breeding and sheep breeding [15-17].

The systemic interconnections of the community's territorial land resources can be represented in the form of the following mental scheme (Fig. 3).

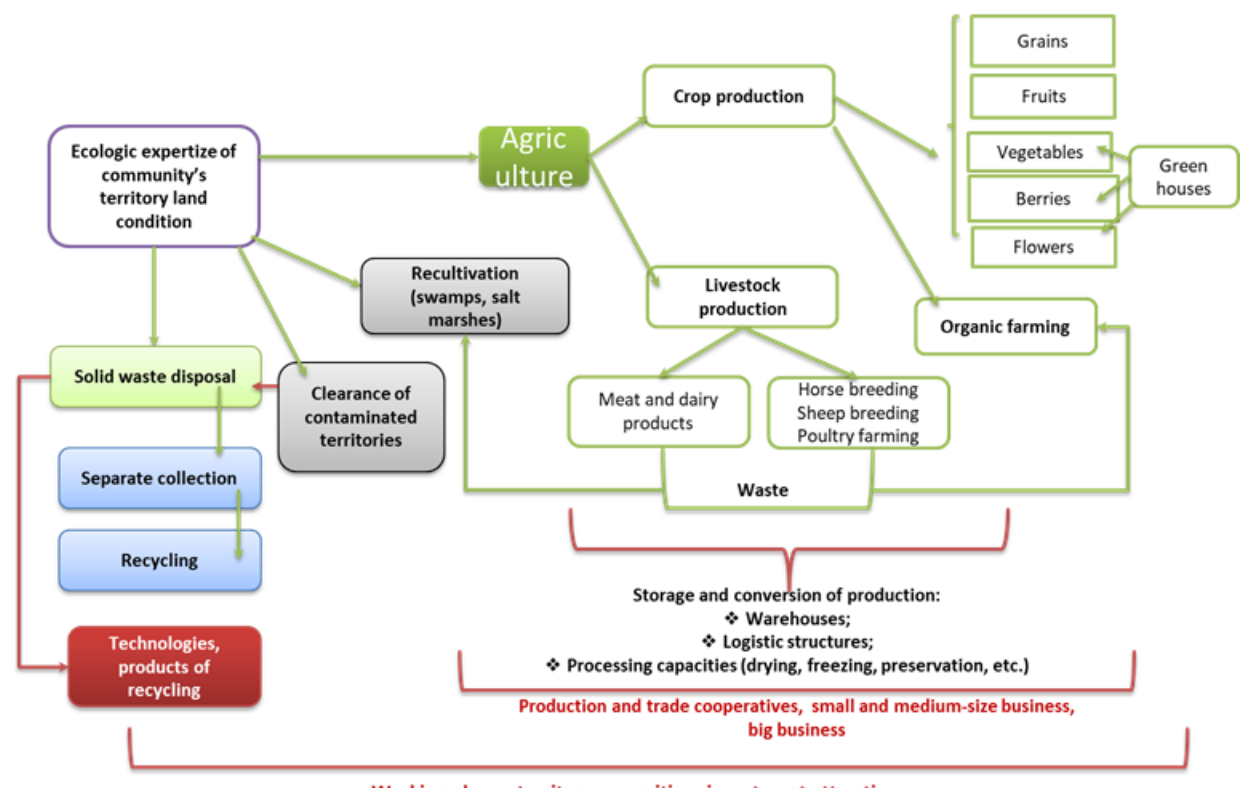

Working places, territory recognition, investment attractiveness

Fig. 3. The potential of the community's land resource and its rational use.

The analysis of the systemic connections of the "land" resource also allows the formation of project pools for the implementation in the sphere of agriculture: 
- development of various areas of crop production (growing vegetables, fruits, berries, as well as industrial crops);

- development of various areas of animal husbandry (meat and dairy production, horse breeding, sheep breeding, poultry breeding, etc.);

- processing of crop and livestock products;

- processing of crop and livestock waste (including new technologically advanced biodegradable materials);

- packing, packaging of processed products;

- freezing of crop and livestock products;

- production of tools for small and medium-scale mechanization of rural labor;

- opening of wholesale markets for agricultural products on the Dnepr-Kharkiv and Dnepr-Donetsk routes.

In addition, given the uniqueness of the geographical location of the territory, it seems interesting to build a warehouse for agricultural products in close proximity to large cities (Dnipro, Kharkiv, Donetsk), highways and railways.

The systematic development of the agricultural sphere allows creating a full cycle on the territory: growing, storage, processing, packing, packaging, sale and delivery to the consumer (Fig. 4).

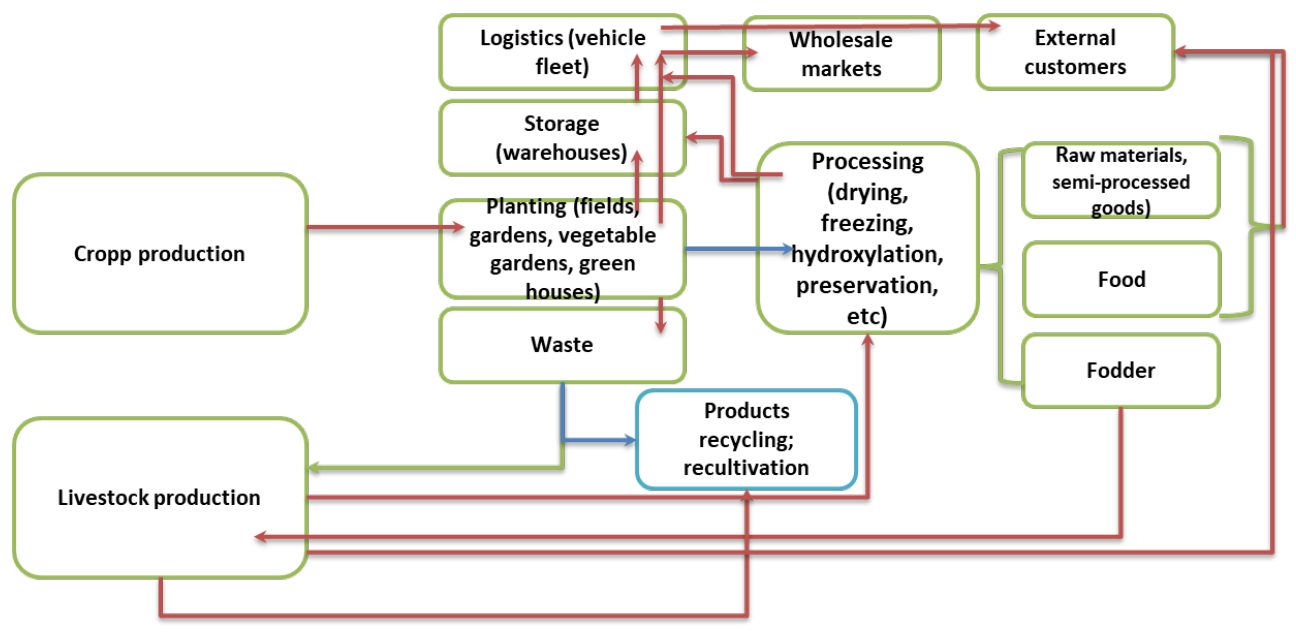

Fig. 4. Systemic development of agricultural sphere.

In addition, on the basis of such resources, it is advisable to develop a common (for example, cooperative) brand of the community in order to increase product recognition.

Also, land resources indicate the possibility of developing resort and health-improving enterprises (possibly on the basis of a unique resource - the health resort "Soleniy Liman"), which, in addition to the traditional treatments, may have other various features, such as: harvesting tourism (with the ability to combine recreation with traditional harvesting processes to suit clients' taste and needs); organization of inclusive education for children suffering from diseases of the musculoskeletal system and cerebral palsy [18-21].

Considering the proximity of several megacities and an ecologically clean forest zone, it is possible to allocate plots for people with high incomes for cottage construction on the territory of the community. On this basis, it is also possible to organize eco-villages with a new environmentally oriented way of management as an experimental platform for the installation of new values in society [22-24]. 


\section{Conclusions}

The carried out studies made it possible to draw conclusions that the development of the territory must necessarily begin with an analysis of the resource base and its features. The mood and dreams of people living on the territory have been taken into account. To manage the territory, a pool of comprehensive structured information is needed, which makes it possible to simulate potential scenarios for the development of a community. At the same time, the heads of self-government bodies actually manage information about economic objects, but not the objects themselves as such. And the presence of structured information allows them to operate possible development scenarios more freely and to influence the situation more actively. Public authorities in Ukraine and abroad are in the process of reforming and it is necessary to ensure the requirements of sustainable development, take care of the environment, conserve land and water resources as a guarantee of their development and the welfare of community residents in the future. And such management is possible if the manager understands the essence of the information that describes his object of management - the territory and the community.

Land and water, like any other economic resources, are in the zone of interests of various economic entities and there is a competition for them. This is especially actual for water resources. If the land in most cases has, according to the law, its owner or tenant, then the situation with water resources is much more complicated. The example of Peshchanka shows that attractive water resources encourage unscrupulous entrepreneurs to act against the interests of the population of the territory, violating the law sometimes.

Rivers and lakes cannot be alienated from the community and require closer attention from the authorities, as well as their management must be based on reliable information about the priorities and preferences of community residents. The given models are quite universal by their nature and can be applied to management of sustainable development of other administrative-territorial entities in the European climatic zone.

\section{References}

1. Ivanova, S., Kvitka, S., Andrienko, M., Dolhyi, O. \& Dolhyi, A. (2020). Information management reducing the risks of agricultural business in organic farming. E3S Web of Conferences, 208, 03020. https://doi.org/10.1051/e3sconf/202020803020

2. Ivanova, S., \& Suetin, A. (2019). Walking through the wilds of information, or Algorithms of understanding: Cognition in the era of ignorance: a tutorial on working with information. Moskow: LENAND.

3. Molokanova, V., \& Olkhovikova, J. (2020). Transformation technologies in the processes of capable territorial communities developing. Public Administration Aspects, 8(2), 87-97. https://doi.org/10.15421/152023

4. Pishchanska village united territorial community (2020) Territorial community. https://pishchanska.otg.dp.gov.ua

5. Hutsaliuk, O., Koval, V., Tsimoshynska, O., Koval, M., Skyba, H. (2020). Risk Management of Forming Enterprises Integration Corporate Strategy. TEM Journal, 9(4), 1514-1523. https://doi.org/10.18421/TEM94-26

6. Gharajedaghi J. (2006). System Thinking: Managing Chaos and Complexity. Butterworth-Heinemann: Elsevier.

7. Mikhno, I., Koval, V., Shvets, G., Garmatiuk, O., \& Tamošiūnienė, R. (2021). Green Economy in Sustainable Development and Improvement of Resource Efficiency. Central European Business Review, 10(1), 99-113. https://doi.org/10.18267/j.cebr.252 
8. Kvasha, S., Pankratova, L., Koval, V., \& Tamošiūnienè, R. (2019). Illicit financial flows in export operations with agricultural products. Intelellectual Economics, 13(2), 195-209.

9. Pauli, G. (2010). The Blue economy: 10 years. 100 innovations, 100 million jobs. Taos NM : Paradigm Publications.

10. Koval, V., Sribna, Y., Mykolenko, O., \& Vdovenko, N. (2019). Environmental concept of energy security solutions of local communities based on energy logistics. GeoConference SGEM 2019, 19(5.3), 283-290.

11. Zelenkevich, L. (2019). Identity in the conditions of the united communities. Scientific and Theoretical Almanac Grani, 22(2), 5-15. https://doi.org/10.15421/171916

12. Arsawan, I.W.E., Koval, V., Rajiani, I., Rustiarini, N.W., Supartha, W.G. \&Suryantini, N.P.S. (2020). Leveraging knowledge sharing and innovation culture into SMEs sustainable competitive advantage. International Journal of Productivity and Performance Management (in press). https://doi.org/10.1108/IJPPM-04-2020-0192

13. Dankeieva, O., Solomianiuk, N., Strashynska, L., Fiedotova, N., Soloviova, Y., \& Koval, V. (2021). Application of Cognitive Modelling for Operation Improvement of Retail Chain Management System. TEM Journal, 10(1), 358-367.

14. Shmygol, N., Schiavone, F., Trokhymets, O., Pawliszczy, D., Koval, V., Zavgorodniy, R., \& Vorfolomeiev A. (2020). Model for assessing and implementing resourceefficient strategy of industry. CEUR Workshop Proceedings, 2713, 277-294.

15. Arsawan, I. W. E., Wirga, I. W., Rajiani, I., \& Suryantini, N. P. S. (2020). Harnessing knowledge sharing practice to enhance innovative work behavior: the paradox of social exchange theory. Polish Journal of Management Studies, 21(2), 60-73.

16. Zolotukhin, V., Gogolin, V., Yazevich, M., Baumgarten, M., \& Dyagileva, A. (2017). Environmental management: the ideology of natural resource rational use. In IOP Conference Series: Earth and Environmental Science, 50, 012027.

17. Yanes, A., Zielinski, S., Diaz Cano, M., \& Kim, S. I. (2019). Community-based tourism in developing countries: A framework for policy evaluation. Sustainability, 11(9), 2506.

18. Izakovičová, Z., Špulerová, J., \& Petrovič, F. (2018). Integrated approach to sustainable land use management. Environments, 5(3), 37.

19. Sabadash, V., \& Denysenko, P. (2018). Economic and social dimensions of ecological conflicts: root causes, risks, prevention and mitigation measures. International Journal of Environmental Technology and Management, 21(5-6), 273-288.

20. Shubalyi, O. M., Kosinskyi, P., \& Golyan, V. (2020). Economic simulation of the development of agriculture in Ukraine due to integrated use of natural resources and waste. Bulgarian journal of agricultural science, 26(2), 323-331.

21. Dupuits, E. (2019). Water community networks and the appropriation of neoliberal practices: social technology, depoliticization, and resistance. Ecology and Society, 24(2), 20. https://doi.org/10.5751/ES-10857-240220

22. Metternicht, G. (2018). Land use and spatial planning: Enabling sustainable management of land resources. Springer.

23. Koval, V., Mikhno, I., Udovychenko, I., Gordiichuk, Ye., \& Kalina, I. (2021). Sustainable Natural Resource Management to Ensure Strategic Environmental Development. TEM Journal (in press).

24. Stinson, J., \& Lunstrum, E. (2021). Biocultural nation making: Biopolitics, culturalterritorial belonging, and national protected areas. Environment and Planning E: Nature and Space, 251484862199518. https://doi.org/10.1177/2514848621995189 